\title{
'FUNDAMENTALISM IN AFRICAN TRADITIONAL RELIGION': A REFLECTION ON SOME POINTS FOR CONSIDERATION
}

\author{
Xolani Sakuba \\ School of Religion and Theology \\ University of KwaZulu Natal
}

\begin{abstract}
This article explores the possibility that, although there is no full-blown 'African fundamentalism', certain fundamentalist tendencies can be detected among adherents of African Traditional Religion. After a summary of typical features of ATR, two area are identified within which fundamentalist tendencies are manifested: the family or clan and public debates driven by (pan-)African nationalist movements or ethnic nationalism. In the latter case the tendencies are often seen purely political, but it is argued that in the African context there is no clear distinction between religion, culture and politics. Moreover, the colonial heritage colours the way in which fundamentalist tendencies are expressed in Africa. In each case various examples are given and assessed to determine whether the tendencies can be called fundamentalist. Finally, the question is asked whether there can be fundamentalism without a scripture. It is suggested that, since ATR has no scriptures, ancestors take the role of ultimate authority.
\end{abstract}

Key words: Fundamentalism, African Traditional Religion (ATR), Tradition, Afrocentricity, Nationalism

\section{Introduction}

To speak of fundamentalism within a context of Traditional African Religion is not an easy exercise - in fact it can be a rather challenging endeavour. Firstly, one has to deal with the question of whether one can legitimately speak of African fundamentalism, ${ }^{1}$ and whether such an attempt would not be seen as just another unnecessary importation of a Western concept into an African context which happens to operate on a completely different worldview. ${ }^{2}$ Secondly, in dealing with fundamentalism in this context, one is also bound to face

\footnotetext{
Looking at both the causes and consequences of religious fundamentalism Steve Bruce (2000:95) observes that religions differ in their potential for fundamentalist movements. In explaining this observation, he argues that Islam and Christianity (especially the evangelical protestant strand) are more prone to fundamentalism. He further contends that "these religions are monotheistic: they believe there is one God. They are also dogmatic: they believe it is possible to express his nature and will in specific propositions to which we must assent." Thereafter argues that both of these characteristics seem to be necessary preconditions of fundamentalism. After making a comparison between these two religions and Eastern religions, he comes to a conclusion that religious fundamentalism as manifest in the two Abrahamic religions he fore-mentioned goes much deeper than what he sees as revival and nationalist movements characteristic of the Eastern religions. Based on this and similar observations, one would wonder whether there is such a creature called African fundamentalism. For more clarity it would be helpful to read Bruce's original argument in this regard.

2 African scholars are becoming highly suspicious of how Euro-American concepts are being smuggled (by both African scholars within and outside the continent and a group of self proclaimed Western Africanists and
} 
the challenges which come with the fact that one has no choice but to appreciate and be fair to the vastness of the African continent as well as the proliferation of various forms of African traditions, especially in terms of the challenge that these poses on any analysis of what is and what is not African. ${ }^{3}$ This matter has been extensively exhausted elsewhere and therefore will not be undertaken in this paper except where it used to clarify a certain point.

Thirdly, when one speaks of African traditional religion you have to deal with the question of what does one mean by religion. Is African tradition a religion? What constitutes a religion and what qualifies African tradition as such? Some might argue that the term religion itself can be very fluid at times and therefore one needs to ask who defines what religion is on what basis? For example, when most people think of a religion, they immediately think of a supernatural being(s) who reveals him/herself at some point in time in his/her own discretion. Concomitantly, people start to think about written documents in which various acts of such a revelation is captured. In other words once you mention religion people start to think of the Quran, the Bible, Bhagavad-Gita, and The Torah. Against this backdrop therefore, some might argue that one has no option but to unpack firstly what he or she means by religion.

Although these are fairly good and relevant starting points for a paper such as this one and are in a way part of long nights of deliberation preceding this paper, I prefer to leave this part to my learned experts within the field of religious studies and pay more attention on what I call 'fundamentalist tendencies' versus fundamentalism within a traditional African religious context.

The first part of this presentation looks at some of the basic features of African traditional religion, especially those features which make ATR unique or different from other world religions. I do this as a way of creating a background for some of the claims I will be making as we proceed further. After that, I go further to look at how fundamentalistic tendencies manifest themselves in various ways and in different levels of our society. In this section, I begin by looking at how fundamentalistic tendencies manifest themselves in a traditional African family setting, such as family meetings and ritual gatherings as well as how such manifestations find their way into public debates especially with regards to debates that deal with current affairs within our societies. The second part of this section on the other hand looks at how fundamentalistic tendencies, which

anthropologists) into African contexts and passed off as African religion or philosophy (see Mcgaffey 1981:248). Perhaps the most sophisticated and detailed analytical response to this phenomenon is that of a Zairean scholar and philosopher VY Mudimbe in his famous book "The invention of Africa: gnosis, philosophy, and the order of knowledge" published in 1988, where he (after arguing that contemporary African scholars/contemporary African scholarship is still operating in paradigms which are rooted in Western epistemological frameworks) proposes alternative ways which may lead to a possibility of a truly African epistemological breakthrough. This concern is also reflected in a number of questions that are being raised with regards to a gullible use of a number concepts which some (scholars) believe are entrenched in Western epistemological paradigms. Such concepts, to name just a few, include commonly used notions such as education, the nation, democracy, history, African renaissance, notions of development, as well as those of philosophy. Also see Harvey J Sindima's critique of both Placide Temples' Bantu Philosophy how his (Tempel's) line of thinking (which according to Sindima (1995:130-135) seeks to explain an African worldview through Western paradigms) finds new expression in the works of two prominent Catholic African Christian theologians, Vincent Mulago and Alex Kagame. Perhaps also interesting is Kwame Appiah's critique of Du Bois' conception of race (see Appiah's chapter on race in, In my fathers house: Africa in the philosophy of culture 1992, Oxford University Press).

3 Again African scholars have been raising a number of serious questions with regards to a number of interdisciplinary discourses on Africa. Most of these questions include questions such as, who qualifies as an African, how one can define one's African-ness, can one speak of Africa as though it was a homogeneous village operating on commonly shared values, etc. 
sometimes translate into full blown fundamentalism, find expression in African nationalist movements such as Pan-Africanism and Afrocentrism. I then conclude by briefly making a few comments with regards to the fact that this seems to be a seriously under-researched topic and that perhaps scholars should start to think seriously about investing their research expertise in this topic. Before we proceed, there are two more things which I think I should explain. Firstly, as you read further, you will soon notice that I start by referring to the phenomenon in question as fundamentalistic tendencies. And then lately this phrase sorts of disappears (and reappears) along the way as I begin to use 'fundamentalism'. I am quite aware that this might come across as inconsistency.

Well, it is not. The truth is I simply prefer to use 'fundamentalistic tendencies' when I refer to certain specific behaviours while I prefer to use 'fundamentalism' each and every time I refer to the phenomenon in general. Secondly, you will soon discover that mine is really not to express or to raise concerns about the perils of African fundamentalism, nor is it a negative review of the entire phenomena. Instead, motivated by an understanding that at the centre of this phenomenon is a general feeling, amongst adherents of a particular religion that certain aspects which are fundamental to their religion are being compromised on the altar of modernisation and globalisation, this paper seeks to show that Africans too at times, albeit in different ways, do share and express the same view(s). In other words, mine is merely to say do not be mistaken, fundamentalism is alive and kicking African traditional religion.

\section{African Traditional Religion: A unique Phenomenon}

Before we look at various forms of fundamentalist religious tendencies/fundamentalism within a traditional African religious context, it is imperative that we take some time and reflect on some of the features that characterise what we call African traditional religion. Firstly, unlike Abrahamic Religions, African traditional religion(s) does not subscribe to the idea of conversion. ${ }^{4}$ In other words all adherents of ATR are born into a religious realm. One may further argue that in some circles even the very act of conceiving a child can be seen as a response to a religious call, a conscious endeavour to preserve life, or to strengthen the family as a way of preserving the legacy of one's clan.

Secondly, ATR finds expression in everything that an African does. As Sindima (1995:126) puts it:

The African universe is one full of life - life transcending itself through fecundity. In its abundant creativity, life continues to cross frontiers and breaking forth into new dimensions, always recreating itself, thereby presenting humankind with ever new possibilities. This self-transcending life is not just 'nature life,' that is material; it is also sacred life. Nature, life, is sacred by origin in the African world, because it is given by God. By the fact of its divine origin the question of life becomes a spiritual issue. Since the cosmos is spiritual, then all considerations about human life have religio-moral implications as well as political ramifications. This means that the question of human life cannot be fully depressed until the religious and moral and political questions have been answered; life has always to be seen in its totality.

In other words, a teleos of one's behaviour may be directly or indirectly determined by what is understood to be right in the eyes of the ancestors who are the sole custodians of their respective clans. Thirdly, because African traditional religion is not an evangelical

I must confess that I do not know how to refer to those white sangomas who claim to have now become experts on traditional African religion. 
religion, and also, because an African traditionalist cannot extricate/remove religion from his/her everyday activities, one may argue therefore that everything that an African does in this world ${ }^{5}$ qualifies as a valid aspect of ATR. In other words, one's actions have a potential to either promote or to hinder communal relationships, which most African traditionalists put at the centre of their understanding of salvation or soteriology, as well as their understanding of $\sin ^{6}$ What does this mean in terms of religious fundamentalism in a traditional African context?

This could mean a number of things. Firstly, this could then mean that extremely conservative parents, who do not allow their children to part-take in certain things simply because the parents in question see those things as complete antithesis of tradition, may be labelled as a fundamentalist. Secondly, all those individuals or groups who take it upon themselves to make public comments about how atrocious it is that people are negating their traditions for foreign religions can surely be tagged as religious fundamentalists. Thirdly, all those Africans who earnestly believe that the supreme integrity of their ethnic groups is under siege from external adversaries and thereby feel compelled to protect it by any means possible are by any means fundamentalists. Fourthly, all those Africans who, although they have officially adopted religions which originate outside the African continent, are still earnestly investing most of their time on making sure that not only do they retrieve fundamental aspects of African traditional religion, but they also preserve them for future generations, are fundamentalists albeit of a different kind. Last but not least, all those Africans both on the mother continent and in the Diaspora, who are vigorously calling for the unity of all Africans, afro-centric ways of understanding and responding to reality, as well as those who through arts and poetry dared to put African aesthetics on world stages believing that it deserves equal appreciation, can on the basis of the scope of African traditional religion be referred to as African fundamentalists.

\section{Various Manifestations of Fundamentalist Tendencies in African Traditional Religion.}

\section{Fundamentalist Tendencies in a Context of an African Family/Clan}

Anyone who wants to understand fundamentalism in African traditional religion cannot afford to ignore fundamentalistic tendencies within a context of an African family. One has to remember that this is where one witnesses a series of clashes between the young generation, which prefers to see itself as more progressive and liberated, and an older generation which sometimes tends to be more conservative and traditional. It is within this context that certain fundamentalistic tendencies become apparent. Within this context there are two scenarios. The first scenario is where you find a family whereby everybody is basically progressive in their ways of thinking. In such a scenario, as progressive as they might be, parents ${ }^{7}$ may still be viewed by their children as conservative and traditional. This is quite normal. For example the same progressive and enlightened parents may still make references to how their own parents taught them how to earn through hard work everything that they wanted, as opposed to how children these days expect to just get

5 No wonder the social dimension of Christianity which finds expression on an emphasis on Christian praxis became the driving force that characterise both Black and liberation theologies which happen to be official mouthpieces of the African bloc both locally and in the Diaspora.

6 For a concise succinct view on the notion of $\sin$ in African traditional religion see Mbiti, (1964, 1989), and Sawyer, (1964).

7 In a traditional African society, it's very important to note that a parent can be anyone or any person within your immediate family, clan, or even your community who happens to be as old as your own parents. 
everything that they want without earning it. Again this is normal. Similarly, the same parents as understanding as they may be may still demand respect from their children, while still lenient when it comes to certain issues. Children might not like this due to different understandings of what is respect between them and their parents. Surely there is nothing abnormal about this as it happens in all nations. Once again, some parents may still value their traditional customs and all that these may entail. They may even expect their children to follow suit. Last but not least, the same modern parents may prefer an authoritarian approach in terms of raising their children. Is this fundamentalism? No. Let us take a look at the second scenario.

Here you have parents who are (usually a father) pathologically or almost obsessively concerned about how his/her family should be brought up in a way that does not deviate from certain traditional fundamentals within their tradition. That is not all; such parents would earnestly keep an eye on every move within his or her family to make sure that things are done appropriately and in accordance with tradition. One should keep in mind that there is a huge difference between the picture I am trying to draw here and the case of a person for whom tradition is simply a matter of convenience. Here I am referring to those individuals whose actions are entirely rooted in genuine convictions about what is right and wrong, pure and profane, as far as tradition is concerned. Here you are looking at people who have gone to the extremes of disowning their children and their families on the basis that they have gone against the truth. You are also looking at people who in some cases have gone as far as to repeatedly abuse their children and spouses for the sake of the truth. You are looking at people who are sitting in jails for killing their spouses on the basis that a wife usually did not show any respect to his husband who according to tradition is the head and cannot be questioned. The irony is that such cases are usually categorised as domestic abuse or violence and never as domestic religious wars or disputes. This is the scenario I am referring to characteristic of fundamentalistic tendencies in traditional African families. Actually, this is fundamentalism. Once again I want to stress that there is abuse (both men and women) in traditional African communities; however, there is a huge difference between common forms of abuse and those that are committed by someone who is genuinely convinced that he or she is fulfilling a religious call.

This usually does not end there. There are times when certain individuals with fundamentalistic tendencies get an opportunity to be together. This usually takes place in a family meeting or gathering whereby all members of a certain clan meet to discuss a dilemma that has befallen the family or clan. Another typical example is when there is a funeral or a traditional feast that usually follows after a ritual has been performed. Meetings such as these usually create a perfect space for local fundamentalists to share their thoughts. Topics in these gatherings usually evolve around unruly wives and children who have turned their backs on tradition, but most importantly, how to deal with such cases of abomination. Again it is also in these gatherings that one witnesses huge verbal fights about what tradition teaches as well as how the young generation is out to undermine those pillars. On a worse scenario, families break. Brothers become worse enemies. Remember there will always be more liberals who are seen as embodiments of evil. This is a group that includes those who are seen to have brought shame and disgrace to their clans and their communities. Have you ever wondered why youngsters exile themselves in big cities and only return home after certain people have died? Now you know.

In this scenario you also have old women who are sometimes accused of witchcraft. With witchcraft being seen as the ultimate sin within a traditional African society, one can only imagine what these poor people go through. 
There is another area where these fundamentalistic tendencies reappear. That is an area of public debates. Unlike in a context whereby you are dealing with family members or members of the same clan working out their internal issues, in this context one is dealing with people from different families and clans engaged in a palaver. My classical example of where these public debates take place is in a public transport. You would be amazed by the level of discussions that are taking place in these trains and buses. Another perfect platform comes in a form of radio talk-shows. Whether its television, talk-shows or radio talk-shows it's all the same. The third platform is newspapers, especially the comments page. African traditionalists with fundamentalistic personalities use these spaces very creatively. On trains, people become engaged in heated debates about a number of issues. Some debates continue for a week or a month until some thing new comes up. Behind these debates are current issues such as gay and lesbians, same-sex-marriage, the ban on corporal punishment in schools, teenage pregnancy and many more. If one listens to these debates it is quite easy to see who is a fundamentalist and who is not. What is also interesting about these debates is that African traditional fundamentalists get an opportunity to share a stage with African Christian fundamentalists.

I want to re-emphasise that any account of fundamentalism in an African traditional society cannot afford to ignore what takes place in these spaces, more so because African Traditional Religion finds expression in all spheres of life and at all times.

\section{Fundamentalist Tendencies in African Nationalist Movements as well as in Ethnic Nationalism}

Traces of fundamentalism in African nationalist movements are probably the most difficult to detect. Three reasons in particular seem to contribute to this situation. Firstly, most of these nationalist movements emerged in the Diaspora and that may raise a number of questions in terms of their status as authentically African movements. Secondly, some might argue that the main agenda with in these movements has more to do with sociopolitical circumstances of the black communities in the Diaspora and far less with issues of religion.

In the light of the possibility that such arguments may arise, it is fitting that we remind ourselves that any argument which supports the existence of fundamentalistic tendencies within an African traditional context exist can only hold water when approached from the point of view of what is African traditional religion. For example, if we say African traditional religion permeates all spheres of life whether domestically, socially, politically, or philosophically, one may argue that the entire project of the negritude, Pan-Africanism, or that of Afro-centrism is a religious expression even though some adherents in question may not always be aware of this fact - most of the time due to a number of reasons. ${ }^{8}$

In conjunction with that, one may therefore be justified in arguing that most struggles that Africans are involved in should not be seen only from the perspective of the implications they may have practically, for there is also a spiritual dimension to some of these struggles.

To understand what I am saying here one needs to look no further than Molefi Asante, known in some circles as the father of Afrocentrism. In his book entitled 'Afrocentricity'

8 Just as Africans were not aware that they were black until they made contacts firstly with Arabs and then with white people, to most Africans, African religion is still merely a way of life.

9 Molefi Asante, born in Georgia in 1942, originally christened Arthur Lee Smith, is a professor and chairperson of the Department of African Studies at Temple University in the United States. 
published in 1988, in a fashion that is only typical of a religious leader starting a sermon, Asante (1988:1) opens by telling his audience that the text he is about to share offers:

a philosophical inquiry into the future of the Afrocentric perspective and a 'Testament of Nija', the ideology of victorious thought. (My emphasis) ${ }^{10}$

Like a joyful and loyal devotee/servant whose mission is to spread the good-news, he proclaims:

Afrocentricity is the centrepiece of human regeneration. To the degree that it is incurporated into the lives of millions of Africans on the continent and in the Diaspora, it will become revolutionary. It is purposeful, giving a true sense of destiny based upon the facts of history and experience. ${ }^{11}$

Soon after that, he addresses his potential convents firstly by issuing a warning to 'thosewho-have-not-yet-seen-the-truth':

The psychology of the African without Afrocentricity has become a matter of great concern. Instead of looking out from one's centre, the non-Afrocentric person operates in a manner that is negatively predictable. The person's symbols, lifestyles, and manners are contradictory and thereby destructive to personal and collective growth and development. Unable to call upon the power of ancestors, because one does not know them; without an ideology of heritage, because one does not respect one's own prophets; the person is like an ant trying to move a large piece of garbage only to find out that it will not move. ${ }^{12}$

After a few words about how his religion (Afrocentricity) will transform Africa and necessarily influence European and Asian thought, he goes on to introduce a number of prophets. Included in his list are Garvey, Du Bois, Fanon, Nkrumah, Muhammed, Malcom and Karenga. Having spent some time explaining African traditional religion in Afrocentric terms, following in the footsteps of 'Prophet Karenga' he warns his audience against syncretism. Elsewhere, he continues his teaching:

Afrocentricity teaches us to honour Jamestown where the first bloods truly destined touched the American earth; to honour Thebes, the most sacred city; to honour Oshogbo where the healing waters flow; to honour Lake Bosumtwi where the God of Africa dwells; to honour the sacred spot where Nat Turner planned his revolt against Virginia. We have within our own history the most sacred and holiest places on earth. Afrocentricism directs us to visit them and meditate on the power of our ancestors. Turning one's head to Mecca is symbolic of the same cultural insistence which keeps the convert looking in the direction of another's culture, not his own. Since for the Afrocentric person, our God is everywhere present, this particular ritual is not understandable. ${ }^{13}$

Having said all that Asante (1988:22-24) then introduces Njia: 'The way', which he refers to as the collective expression of the Afrocentric worldview which is grounded in the historical experience of the African people. ${ }^{14}$ Njia represents the inspired Afrocentric spirit found in the traditions of African-Americans and the spiritual survival of an African essence in America - it is found among African Americans but also exists in several African countries. ${ }^{15}$ Njia becomes the main source of meditative activities and spiritual

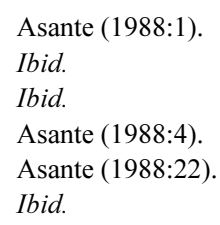


growth. ${ }^{16}$ When Njia is accepted, all things seem new, old things no longer please or seem adequate - Njia establishes a link to our fundamental, primordial truths. ${ }^{17}$ Asante further explains that practices of Njia and teachings of Njia constitute the beginning of reconstruction. It bases reconstruction on Afrocentricity which becomes sacred to its teachings Njia is both the name of the book and the name of the gathering for when you meet in Njia you gather around the teachings of Njia. There are six parts to a Njia meeting which are designed to incorporate the spirit into a functional aspect of life. These are:

- Libation

- Poetry, music creativity and expression

- Nommo: generative Word Power

- Affirmation

- Teachings from Njia

- Libation to Posterity

This is a pattern which has become a permanent part of Njia and does not vary. ${ }^{18}$

Perhaps the most striking example of African fundamentalistic sentiments finds expression in a powerful prose titled 'African fundamentalism' by Murcus Garvey, ${ }^{19}$ a Jamaican Pan-Africanist, in 1925 during his time in America:

A Racial Hierarchy and Empire for Negroes

Negro's Faith must be Confidence in Self

His Creed: One God. One Aim. One Destiny

The time has come for the Negro to forget and cast behind him his hero worship and adoration of other races, and to start out immediately to create and emulate heroes of his own. We must canonize our own saints, create our own martyrs, and elevate to positions of fame and honour black men and women who have made their distinct contributions to our racial history. Sojourner Truth is worthy of the place of sainthood alongside of Joan of Arc: Crispus Attucks and George William Gordon are entitled to the halo of martyrdom with no less glory than that of the martyrs of any other race. Toussaint L'Ouverture's brilliancy as a soldier and statesman outshone that of a Cromwell, Napoleon and Washington; hence, he is entitled to the highest place as a hero among men. Africa has produced countless numbers of men and women, in war and in peace, whose lustre and bravery outshine that of any other people. Then why not see good and perfection in ourselves? We must inspire a literature and promulgate a doctrine of our own without any apologies to the powers that be. The right is ours and God's. Let contrary sentiment and cross opinions go to the winds. Opposition to race independence is the weapon of the enemy to defeat the hopes of an unfortunate people. We are entitled to our own opinions and not obligated to or bound by the opinions of others.

If others laugh at you, return the laughter to them; if they mimic you, return the compliment with equal force. They have no more right to dishonour, disrespect and disregard your feeling and manhood than you have in dealing with them. Honour them when they honour you, disrespect and disregard them when they vilely treat you. Their arrogance is but skin deep and an assumption that has no foundation in morals or in law. They have sprung from the same family tree of obscurity as we have; their history is as rude in its primitiveness as ours; their ancestors ran wild and naked, lived in caves and in

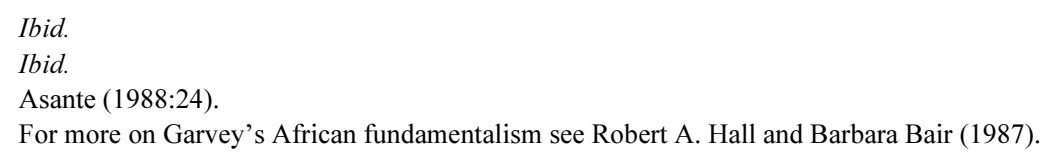


branches of trees, like monkeys, as ours; they made human sacrifices, ate the flesh of their own dead and the raw meat of the wild beast for centuries even as they accuse us of doing; their cannibalism was more prolonged than ours; when we were embracing the arts and sciences on the banks of the Nile their ancestors were still drinking human blood and eating out of the skulls of their conquered dead; when our civilization had reached the noonday of progress they were still running naked and sleeping in holes and caves with rats, bats and other insects and animals. After we had already fathomed the mystery of the stars and reduced the heavenly constellations to minute and regular calculus they were still backwoodsmen, living in ignorance and blatant darkness.

The world today is indebted to us for the benefits of civilization. They stole our arts and sciences from Africa. Then why should we be ashamed of ourselves? Their modem improvements are but duplicates of a grander civilization that we reflected thousands of years ago, without the advantage of what is buried and still hidden, to be resurrected and reintroduced by the intelligence of our generation and our posterity. Why should we be discouraged because somebody laughs at us today? Who can tell what tomorrow will bring forth? Did they not laugh at Moses, Christ and Mohammed? Was there not a Carthage, Greece and Rome? We see and have changes every day, so pray, work, be steadfast and be not dismayed.

As the Jew is held together by his religion, the white races by the assumption and the unwritten law of superiority, and the Mongolian by the precious tie of blood, so likewise the Negro must be united in one grand racial hierarchy. Our union must know no clime, boundary or nationality. Like the great Church of Rome, Negroes the world over must practice one faith, that of Confidence in themselves, with One God! One Aim! One Destiny! Let no religious scruples, no political machination divide us, but let us hold together under all climes and in every country, making among ourselves a Racial Empire upon which 'the sun shall never set.'

Let no voice but your own speak to you from the depths. Let no influence but your own rouse you in time of peace and time of war; hear all, but attend only to that which concerns you. Your allegiance shall be to your God, then to your family, race and country. Remember always that the Jew in his political and economic urge is always first a Jew; the white man is first a white man under all circumstances, and you can do no less than being first and always a Negro, and then all else will take care of itself. Let no one inoculate you with evil doctrines to suit their own conveniences. There is no humanity before that which starts with yourself, 'Charity begins at home.' First, to thyself be true, and 'thou canst not then be false to any man.'

God and Nature first made us what we are, and then out of our own created genius we make ourselves what we want to be. Follow always that great law. Let the sky and God be our limit and Eternity our measurement. There is no height to which we cannot climb by using the active intelligence of our own minds. Mind creates, and as much as we desire in Nature we can have through the creation of our own minds. Being at present the scientifically weaker race, you shall treat others only as they treat you; but in your homes and everywhere possible you must teach the higher development of science to your children; and be sure to develop a race of scientists par excellence, for in science and religion lies our only hope to withstand the evil designs of modern materialism. Never forget your God. Remember, we live, work and pray for the establishing of a great and binding racial hierarchy, the founding of a racial empire whose only natural, spiritual and political limits shall be God and 'Africa, at home and abroad.'

(New York, the Negro World, June 6, 1925, Front Page Editorial)

As you read this section you might be asking yourself, where other African nationalists fit into this equation. If you are asking yourself that question I am glad. It means you are with 
me. If not, do not be concerned - it simply means that you are not familiar with this field of African discourse. Let us for example take Leopold Senghor a French groomed co-founder of negritude and former Senegalese president. Is he also a fundamentalist? No he is not. In my view, Senghor comes across as more progressive and liberal in his way of thinking. On those grounds, one could argue that he is more of an apologetic compared to Asante. For example, although you could say that he qualifies as an African traditionalist on the basis of the fact that there is no significant difference between African culture (which he spent almost his entire life trying to promote) and African tradition, unlike Asante, his conception or notion of culture seems to have been designed more for a Western audience. ${ }^{20}$ The fact that Senghor seems to have had a number of reservations about certain aspects of African traditional religion ${ }^{21}$ would not have been well received by Asante and those who share his thoughts. One can therefore conclude that Senghor belongs with all those who are likely to be seen by the likes of Asante as been corrupted by the ultimate evil (the West and all its distortions), perhaps in the same way that those who hold a liberal view within the Christian faith would be seen by protestant fundamentalists as been corrupted by modernist positivism. As a result, Senghor does not make it into Asante's list of prophets. This brings me to another point which I think is crucial at this stage of our discussion.

That is, apart from those figures to whom one could easily refer as fundamentalists, there are also those whom I prefer to call 'crypto-fundamentalists'. In this category one finds a number of African fundamentalists or people with fundamentalist tendencies, who nevertheless officially belong to one of the major world religions more especially Christianity and Islam. This is a very interesting group in the sense that perhaps seeing that theirs will never be taken serious, they choose to remain wherever they are (since many of them were brought up or even obtained their education through institutes run by these religious traditions) and use whatever platform or means possible to further their cause. One could argue that Asante is aware of this group of Africans. For example, in his list he includes Garvey (a Christian), Nkrumah (another Christian), as well as Muhammed and Malcolm (both Muslims). Once again, Senghor does not make it into this category. There are other figures who I think should be included in the list of those whom I call cryptofundamentalists. Those would be: Gabriel Setiloane, John Mbiti, Steve Biko, and Cheik Anta Diop.

In addition to African fundamentalistic tendencies within African nationalism, another phenomenon whereby African fundamentalist tendencies tend to be more common is that of ethnic nationalism, whereby ethnic identities are appropriated to promote a national agenda or whereby a national agenda is rooted on a particular group's ethnic identity. Closer to home a typical example of ethnic nationalism finds expression in what is known as ' $Z u l u$ Nationalism'. The Zulus under the auspices of the Inkatha Freedom Party (IFP) at some stage strongly believed that theirs was for the sake of the Zulu Tradition Culture. One should note, however, that while the majority of the Zulus display an attachment to their unique cultural identity on individual level, this ethnically defined identity does not necessarily translate into a common political affiliation (Hampton 1998:10). As much as it is true (precisely for reasons such as the one stated above) that one needs to look at cases such as this one carefully, ${ }^{22}$ especially when issues of power and politics are involved, it is

20 See John Reed and Clive Wake, 1976. Senghor: prose and poetry. Melbourne: Oxford University Press, (6975) and (96-99).

21 Ibid (37-42).

22 For example, Hampton (1988:16) has made it clear that the decision of the IFP leadership to present its party as the defender of Zuluness had all the signs of instrumentalism. In other words more than anything else, 
also true that the approach which the leaders of the IFP followed in their campaigns aroused $^{23}$ in the Zulus genuine deep seated sentiments concerning their traditions and customs. ${ }^{24}$ In other words, for those Zulu nationalists within the IFP, to whom issues of Zulu tradition and culture meant life and death, Inkatha was and still is the only hope for the reinstatement of an untainted and an authentic Zulu nation with all its former glory. However, it should be clear that despite Inkatha's efforts, Zulu ethnicity, arising on the basis of a shared cultural identity did not provide the basis for an all encompassing nationnalism, whereby the Zulus unite behind a common political agenda (Hampton (1998:10). Using Zulu culture and tradition as but one aspect of African traditional religion, on the basis of various forms of extremism, intolerance, expressions of supremacy of the Zulu culture and a series of violence which are characteristic of the IFP in the late eighties and early nineties, are but one form of religious fundamentalism in African traditional religion.

Last but not least, the same could be said of the conflict which left the entire world in shock in the nineties in the great lakes region particularly the Rwanda genocide. As much as some scholars ${ }^{25}$ have quite correctly argued that the clash between the Hutus and the Tutsis of Rwanda was to a relatively large extent orchestrated by colonial agents who (through a policy of divide and rule) played these groups against each other by making one group believe that it was inherently superior than the other, it is also true that such incitements may have triggered already deep seated self-perceptions of superiority which amongst other things surfaced out of traditional religious consciousness of superiority. As Bruce (200:9) puts it:

Religion is not just a convenient sign of difference (like the contrasting colour shirts of opposing football teams); it is also often deeply embedded in the sense of ethnic or national identity. It provides each side with a justification for seeing itself as superior (we obey God) and the enemy as inferior (they are infidel)... Fundamentalism may derive its character not just from arguments with some body of believers about what god requires but also from largely secular nationalist struggles. We will not understand fundamentalism if we try to divorce it from the social, economic and political contexts in which it arises.

Is the reciprocal relationship between fundamentalism and nationalism unique in African traditional religion? Is there no relationship between fundamentalism and nationalism in religions such as Christianity, Islam, Judaism, Buddhism, etcetera? History tells us that the truth is the opposite. Ruthven ${ }^{26}(2004: 129)$ argues that while some scholars see

Inkatha leadership sought to use Zulu ethnicity as an ideology to justify the preservation of its regional power base. For more on ethnic nationalism see an essay by Walker Connor, "A nation is a nation, is a state, is an ethnic group" in Hutchinson and Smith (1994:36-46), Hutchinson (1994:40), and Crowford Young, "Nationalism and ethnic conflict in Africa" in Guibernau and Hutchinson (2001:143-163).

23 More especially amongst the rural IFP constituencies of KZN, where the Amakhosi (chiefs) and the Izinduna (headsmen) were and are still in control (not that there were other rural IFP constituencies other than those in $\mathrm{KZN}$ ).

24 Commenting in this issue Campbell (1992:614-621) observed that Inkatha enjoyed more success in areas wherein community elders found their authority and status challenged by the youth.

25 For example, see a brilliant analysis by Mahmood Mamdani in "When victims become killers" 2001 by Princeton University Press.

26 Please note that I am aware of other prominent figures some of them legends, whose contribution within the field of religion and nationalism precedes that of Ruthven. However, what makes Ruthven's contribution more critical in this case is that unlike Durkheim (1947), Weber (1946), Schleimacher (1994), Geertz, Rudolf Otto (1978), Gerardus van der Leeuw (1963) or Rousseau (1987), Ruthven, although drawing from these figures, looks at this relationship strictly from the perspective of religious fundamentalism. Based on that, it is also fair to note that a relationship between religion and nationalism can be highly complex. To understand the 
fundamentalism (religious) and nationalism as rival ideologies, in America, as in Israel, the movements are often barely distinguishable. He goes further to say 'faith in the nation' though it still resonates through socially conservative, military-connected networks inside and outside the United States, has been appropriated in a symbolic sense by fundamentalists. In the same way, he argues that American fundamentalism perceive no conflict between religion and patriotism. Like their puritan predecessors, he explains, they identify America with Israel as a land covenanted to God's people on condition that they followed God's laws. Ruthven (2004:131) makes a somewhat similar observation about Islam; he argues that the Prophet Muhammad triumphed over his enemies through battle as well as by preaching. He further states that building on the Prophet's victories as well as his (The Prophet) obedience to God, his successors, the rightly guided Caliphs, conquered most of West Asia and North Africa as well as Spain. In this view, argues Ruthven (2004:131), the truth of Islam was vindicated on the plane of real time history, through historical achievement in creating what would become a great world civilization. Ruthven (2004:132), far from being counter-nationalist, as argued by some scholars and ideologists, presents the fundamentalist argument that God rewards righteousness in terms of national success and this worldly prosperity is one that chimes in well with nationalist aims. Ruthven (2004:132) on the other hand does nevertheless acknowledge the fact that theoretically fundamentalism and nationalism are sometimes seen as ideological opponents. ${ }^{27}$ Having acknowledged that, Ruthven (2004:135) returns to his original position by arguing that it would be wrong to see nationalism as completely anti-religious and secular. He argues that nationalism has been permeated by religious symbols, especially in places where the core identities that came to constitute nationhood had been buttressed by religious differences. Expounding on this point he argues that different identities that made up Britain were sustained by Presbyterianism in Scotland, non-conformity in Wales, and Catholicism in Ireland, Poland and Croatia, Greece and Serbia by eastern Orthodoxy, Malaysia by Islam, Tibetan, Thailand, and Sri Lanka by Buddhism.

Apart from showing how nationalism as well as how certain nationalistic sentiments are inextricably rooted in certain religious beliefs, Ruthven (2004:153-191) goes further to explain how religious language and symbolism are being appropriated into secular language and symbolism within a number of national movements. He begins his argument with the following quote from Fyodor Dostoyevsky in The Possessed:

The object of every national movement is only the seeking for its god, who must be its god, and the faith in him as the only true one. God is the synthetic personality of the whole people taken from its beginning to its end.

Comparing the above statement with the religious sociology of Emil Durkheim who equated the sacred with the spirit of community, a projection of the communal spirit onto a supernatural, transcendental being, he argues that like religious communities, the nations are collectivities that transcend the sum of their individual parts. Like religious communities, nations bear witness to the idea that human blood must be shed in their defence - the war memorials, cenotaphs, Tombs to the Unknown Warrior that grace our cities attest to transcendental demands the nation makes of its citizens. Using extracts from an address by

depths of this complexity, see Steven Grosby, "Nationality and Religion" in Guibernau, and Hutchinson (2001:119).

27 On this point, Ruthven concurs with a number of other scholars, amongst them Bruce Lawrence and Abul Ala Maududi. Lawrence (1989:83) holds the view that nationalism is in essence an outcome of the industrial revolution and the progressive modernist ideologies that emerged from it. Maududi on the other hand refuses to see any links between secular forms of nationalism and religion, especially Islam. 
the Irish patriot Padraic Pearse, architect of the 1916 rebellion against Britain made at the graveyard of an earlier nationalist, the Fenian Jeremiah O'Donovan Rossa in August 1915 as an example, Ruthven further shows how nationalists prefers religious language (such as baptism, exaltation, communion, holy, and spirit) against the empirical language of politics. Ruthven (155-168) also traces this predisposition in the way the biblical story of Exodus had and to a certain extent still has a major influence on the construction of American identities, Scottish-Irish Protestants in Ulster, Afrikaners of South Africa, and more especially present-day Jewish societies, especially those in the Diasporas.

\section{Politics or Religious Fundamentalism}

Can forms of religious fundamentalism in African traditional religion be the same as those of other religions such as Christianity and Islam? My answer to that question is no and I would like to explain why. Firstly, one needs to understand that the roots of the demise of African traditional religion started with two phenomena, which are both related in politics albeit in different ways, i.e. colonialism and slavery. The colonial agency with its Christian arm (the missionaries) carefully orchestrated ways and means of turning Africans against their own culture and traditional values and effectively their own religion. In this process Africans suffered and went through a great deal of humiliation ${ }^{28}$ and identity crisis ${ }^{29}$ which left them in a limbo. To some extent, this resulted into some form of what A.A. Phillips calls cultural cringe. ${ }^{30}$ Because of this situation, one may argue that African traditional fundamentalists will always (to some extent) be cautious not to step on the toes of the masters as well as those Africans who are still in complete denial; otherwise there will be some whipping. ${ }^{31}$ One can therefore argue that traditional African forms of fundamentalism should be understood within the context of the broader history of colonialism and slavery in Africa. One might argue that a lack of violence in most forms of African fundamentalistic

28 Three incidents in Chinua Achebe's " Things fall apart" offers us a clear illustration of the kind of humiliation Africans had to endure during the early days of colonialism and missionary enterprise in the African continent. The first incident is when Okwonkwo, a loyal traditionalist is humiliated, while in exile, by his son Nwoye who despite knowing his father's wishes and as well as the position his father holds in the community, went and joined the Christian religion. Even though Okwonkwo was a very proud man and would not have wanted people in the village to see him as weak, his humiliation became obvious when he actually stated that he wished Ezinma, his daughter from his second wife Ekwefi, was a man (138-140). The second incident is when the villagers gave the church authorities a piece of land in the Evil forest with the hope that the gods and the evil spirits will eventually come out and wipe out the entire Christian community. Perhaps the most humiliating part about this whole incident is that things did no go according to the villager's wishes. It seemed to them that their gods abandoned them or were weaker than the Christian god (135-137). The last humiliating incident is when Okwonkwo and a group of men with high ranking titles from the village were incarcerated and got their heads shaved by the prison guards against their will, an incident which they probably saw as degrading (175-177). This happened after a group of villagers burnt a church building in protest for the killing of a royal python by of the new convents.

29 Frantz Fanon (1967) offers a brilliant analysis of this in Chapter six of his book "Black skin white masks."

30 "Cultural cringe, in cultural studies and social anthropology, is an internalized inferiority complex which causes people in a country to dismiss their own culture as inferior to the cultures of other countries. The Cultural Cringe is tightly connected with 'Cultural alienation', that is, the process of devaluing or abandoning one's own culture or cultural background. A person who is culturally alienated places little value on their own or host culture, and instead hungers for that of a - sometimes imposed - colonising nation" see http://en.wikipedia.org/wiki/Cultural_cringe. For more on this term, also see Phillips, AA 2006. AA Phillips on the cultural cringe, Melbourne: Melbourne University Press.

31 The word whipping here is used metaphorically to refer to verbal condemnations likely to be unleashed by those who might see themselves as masters in the subject in question, as well as to remind the reader of the abuse which slaves both in Africa and in the Diaspora endured whenever they were seen as unruly and rebellious. 
tendencies may be linked to this, despite the fact that not all violence is fundamentalist and not all fundamentalists are violent (Bruce: 2000:8). This brings us to another point, which I think is very crucial for any one who wants to understand fundamentalism in Africa. That is, African traditional religious fundamentalists (besides the fact that African traditional religion finds expression in all human activities) are compelled to use political platforms and politics as appropriate channels to express their fundamentalist views albeit in disguise. In other words, while African fundamentalists can be as inflexible as fundamentalists from other religious traditions, their history does not leave them enough room for that kind of approach. In other words, a distinction such as the one which Hutchinson (1994:40) makes between 'cultural and political nationalism' does not necessarily apply in a traditional African context for there is not a clear line between culture and politics.

Apart from that there are also other existential factors which include the fact that the Western worldview (in a number of ways) is still consistently dominant in Africa. Mudimbe (1988:41-42), drawing from Eboussi-Boulaga, reminds us that even in the commitment of present-day African philosophers and social scientists, one might find, subtle and silent, the acceptance of the thesis of the Western philosophical model as a 'rationalité en acte.' Similarly African fundamentalists can not completely divorce themselves from some of the things which ultimately force them (one might argue) to betray some of their African values. For example, due to the high rate of unemployment, women are leading families 'dethroning' men from what according to tradition are leadership positions of men. Because of globalization following the introduction of money economy coupled with the culture of materialism in Africa, African fundamentalists have no choice but to be selective and accommodative in their approach. Bruce (2000:15) makes a similar observation with regards to Islam.

An irony of fundamentalism is that they often combine a commitment to a selectively imagined past with an easy facility with modern technology. Because the establishments the fundamentalists oppose control the major forms of communication and the main social institutions, the dissidents are often at the forefront of exploring alternative technologies and social structures. In Iran, the Shah controlled radio, television, the press, the army, schools and political institutions. So the ayatollah Khomeni spread his teachings by audio cassette and by loose networks created by enthusiastic supporters. Osama Bin Laden used fax machines and satellite telephones to control his international network of Islamic terrorists. The American Christian Right built its networks with computerised direct mailing list, toll-free telephones and its own Christian cable networks

\section{What about the Scriptures?}

The fact that there is no book of Revelation, which may be used as a code of reference in African traditional religion, may raise a number of questions. For example, some may doubt whether it is possible at all to speak of religious fundamentalism in an absence of such a code of reference. Sceptics would probably argue that for someone to be a fundamental one at least needs a code of reference to which he or she is uncompromisingly holding on. They would go further to argue that without such a code of reference, fundamentalism is not possible. At this stage, just maybe, the question we should be asking ourselves is whether it is true to say one can not be a fundamental without some allegiance to a specific code of reference. Another question which I think is worth asking at this juncture is whether there is any truth in saying that African religion lacks such a code. Responding to a question from one of the participants in a conference in at the University of the Western Cape in Cape Town, where I shared my views on this topic for the first time, 
I argued that in African traditional religion ancestors occupy a very crucial position. Not only are they custodians of moral values and order in their respective communities, they also play a role of being mediums of communication between God and the living. I further argued just as God spoke through His prophets, so is He doing through the ancestors, albeit in a different way. What then does this mean in terms of the question around the issue of the absence of the code of reference in African traditional religion(s)? My answer is that if ancestors are custodians of the will of Qamata (Xhosa), Modimo Sotho (Tswana), Mvelinqgangi (Zulu), Nkulunkulu (Zulu-Xhosa) on earth, surely all the wisdom that is communicated by the ancestors to the living and passed down through a long tradition of story telling can be seen as symbolic of a code of reference where God and His (sic) will is revealed. ${ }^{32}$ Consider the following passage from a conversation between Akunna and $\mathrm{Mr}$. Brown (a missionary) in Achebe's 'Things fall apart':

"You say there is one supreme God who made heaven and earth", said Akunna on one of Mr Brown's visits. "We also believe in Him and call Him Chukwu. He made all the world and the other gods."

"There are no other gods," said Mr Brown. "Chukwu is the only God and all others are false. You carve a piece of wood - like that one" (he pointed to the rafters from which Akunna's carved Ikenga hanged), "and you call it a god. But it is still a piece of wood".

"Yes," said Akunna. "It is indeed a piece of wood. The tree from which it came was made by Chukwu, as indeed all minor gods were. But he made them for His messengers so that we could approach Him through them. It is like yourself. You are the head of your church."

"No," protested Mr Brown. "The head of my church is God Himself." "I know," said Akunna, "but there must be a head in this world among men. Somebody like yourself must be the head here."

"The head of my church in that sense is in England."

"That is exactly what I am saying. The head of your church is in your country. He has sent you here as his messenger. And you have also appointed your own messengers and servants. Or let me take another example, the District Commissioner. He is sent by your king."

"They have a queen," said the interpreter on his own account.

"Your queen sends her messenger, the District Commissioner. He finds that he cannot do the work alone and so he appoints kotma to help him. It is the same with God, or Chukwu. He appoints the smaller gods to help Him because His work is too great for one person."

"You should not think of Him as a person," said Mr Brown. "It is because you do so that you imagine He must need helpers. And the worst thing about it is that you give all the worship to the false gods you have created."

"That is not so. We make sacrifices to the little gods, but when they fail and there is no one else to go to we go to Chukwu. It is right to do so. We approach a great man through his servants. But when his servants fail to help us, then we go to the last source of hope. We appear to give greater attention to the little gods but that is not so. We worry them more because we are afraid to worry their Master. Our fathers knew that Chukwu was the Overlord and that is why many of them gave their children the name Chukwuka - Chukwu is Supreme'."

\footnotetext{
32 For more on African names of God see an index of African peoples and their names of God in Mbiti's "Concepts of God in Africa," 1970
} 
"You said one interesting thing," said Mr Brown. "You are afraid of Chukwu. In my religion Chukwu is a loving Father and need not be feared by those who do His will."

"But we must fear Him when we are not doing His will," said Akunna. "And who is to tell His will? It is too great to be known" (163).

\section{BIBLIOGRAPHY}

Achebe, A 1958. Things fall apart. Nairobi: Heinemann.

Asante, MK 1988. Afrocentricity. Eritrea: Africa World Print.

Bruce, S 2000. Fundamentalism. Oxford: Blackwell Publishers.

Connor, W 1994. A nation is a nation, is a state, is an ethnic group, is a ... In: Hutchinson, J and Smith, AD (eds.) 1994. Nationalism, 36-46. New York: Oxford University Press.

Fanon, F 1967. Black skin white masks. New York: Grove Press.

Grosby, S 2001. Nationality and religion. In: Guibernau, M and Hutchinson, J (eds.). Understanding nationalism, 97-119. Cambridge: Polity Press.

Guibernau, M and Hutchinson, J (eds.) 2001. Understanding nationalism. Cambridge: polity Press.

Hampton, K 1998. The decline of Zulu nationalism as a defining feature of IFP policy. Masters Thesis: Submitted in The Department of Political Studies, Faculty of Arts , University of Natal, Pietermaritzburg.

Hill, RA and Bair, B 1987. Marcus Garvey: Life and lessons, a centennial companion to the Marcus Garvey and universal Negro improvement association papers. London: University of California Press.

Howe, S 1988. Afrocentrism: Mythical past and imagined homes. London: Verso.

Hutchinson, J and Smith, AD (eds.) 1994. Nationalism. New York: Oxford University Press.

Mamdani, M 2001. When victims become killers: colonialism, nativism, and the genocide in Rwanda. Cape Town: David Philip.

Mudimbe, VY 1988. The invention of Africa: Gnosis, philosophy, and the order of knowledge. Bloomington and Indianapolis: Indiana University Press.

Reed, J and Wake, C 1976. Senghor: Prose and Poetry. Nairobi: Heinemann.

Ruthven, M 2004. Fundamentalism: The search for meaning. Oxford: Oxford University Press.

Sindima, HJ 1995. Africa's agenda: The legacy of liberalism and colonialism in the crisis of African values. London: Greenwood Press.

Young, C 2001. Nationalism and ethnic conflict in Africa. In: Guibernau, M and Hutchinson, J (eds.) 2001. Understanding nationalism, 164-181. Cambridge: polity Press. 